\title{
Examination and determination of the incentive policies effective in increasing the voluntary insurance (life insurance) demands in Tehran
}

\author{
Kiumars Sharifi \\ Assistant Professor, Faculty of Management, Tehran University, Iran \\ Saba Sharifi \\ MBA, Faculty of Management, Tehran University, Iran \\ EInaz Rahrovy \\ Master of MBA, Tehran University, Iran \\ Shima Shahmohammadi \\ Master of MBA, Tehran University, Iran \\ Accepted: Sep 13, 2013 Published: October 01, 2013 \\ Doi:10.5296/ijld.v3i5.4362 URL: http://dx.doi.org/10.5296/ijld.v3i5.4362
}

\begin{abstract}
One of the major factors of the non-development of the life insurance in the country is people's lack of awareness of the advantages of such these insurances. Since the life insurance services are not objective and making people familiar with these services needs providing detailed information, the development of the effective incentive policies of the insurance companies increases the life insurance demands. So the research is to identify and determine the incentive policies to increase the life insurance demands.

Data were collected by questionnaires and the validity of the questionnaire was measured using Cronbach's Alpha test. The method of the present research is a descriptive-correlation one and the hypotheses were tested using the average test and correlation method and SPSS Software, duplicate 19. The results of the research are presented in two descriptive and inferential statistics sections. In the inferential statistics section, the measures effective in increasing life insurance demands were indentified using Spearman's correlation coefficient test and the average test. Also, Friedman analysis of variance test was used to rank the measures of the research and the results showed that the measures including informing the employees of the private companies indirectly, informing the employees of the public companies indirectly, holding sales meetings, giving incentive discounts, giving awards and gifts, producing life insurance-based films and TV serials, and introducing the products and the performance of the company through TV marketing had respectively the first to the seventh ranks in terms of increasing the life insurance demands.
\end{abstract}

Keywords: life insurance, incentive policies, demand

\section{Introduction}

Today's world is a world with very extensive changes in economic and social matters, a world where "economy" is very dominant. In today's network-based economy, companies can be successful in the competition that are equipped with economic promoting tools and use modern information and communication methods to exploit their capitals and resources better. 
In any business, competitive practices become popular one after another. For meeting the speed of competition, the insurance industry also has to use suitable methods and strategies to increase the demands for its products, especially life insurance.

It seems that one of the major factors of the non-development of the life insurance in the country is people's lack of awareness of the services of such these insurance policies. Since the life insurance services are not objective and life insurance is a sellable product, not a buyable product, the incentive activities of the insurance companies increase people's awareness.

Therefore at the present competition age, life insurance companies need effective incentive policies very much to get a bigger share of the market and attract more customers and generally, to increase the volume and the value of the life insurance.

According to what was mentioned above, the research is to increase the life insurance demands by examining and exploring the incentive policies and giving the necessary suggestions.

\section{Problem description}

The major problem that presently exists about the life insurance demand in the country is that a few people use this insurance. One way to increase the share of such these insurance policies in the income of the families is to use incentive policies in order that the demands of such these insurances are increased using these policies. So in this research, the incentive policies effective in increasing the life insurance demands will be examined.

The major purpose of the research is to identify the incentive policies effective in increasing voluntary insurance (life insurance) demands and the minor purposes of the research are as follows:

- Identifying the relationship between advertisement and the increase of the voluntary insurance (life insurance) demands

- Identifying the relationship between personal selling and the increase of the voluntary insurance (life insurance) demands

- Identifying the relationship between sales promotion and the increase of the voluntary insurance (life insurance) demands

- Identifying the relationship between public relations and the increase of the voluntary insurance (life insurance) demands

So the questions of the research are proposed as follows:

The major question: what are the incentive policies effective in increasing voluntary insurance (life insurance) demands?

\section{The minor questions}

- Does advertisement increase the voluntary insurance (life insurance) demands?

- Does personal selling increase the voluntary insurance (life insurance) demands?

- Does sales promotion increase the voluntary insurance (life insurance) demands?

- Do public relations increase the voluntary insurance (life insurance) demands?

\section{The importance of the research}

Insurance is an effective means to compensate for financial losses due to accidents, supply the future, promote the living level of the people of the society and provide a secure condition for 
the economical growth and development of the country. Among different types of insurance, the life insurance is very important due to its remarkable advantages.

Despite many advantages of the voluntary insurances including the life insurance, these insurance policies are not so much welcomed in the country. It can have different reasons, including cultural obstacles, customers' lack of awareness of these insurances and unsuitable incentive policies.

According to what was mentioned above, the research is to examine and determine the incentive policies effective in increasing voluntary insurance (life insurance) demands by examining the incentive policies offered in the insurance industry of the country, in order that the life insurance demands are increased by giving solutions.

\section{Literature review and history of the research}

\section{Factors effective in the life insurance demands}

Life insurance demands are affected by different factors including the economic factors. For example, the current rate of interest, per capita income, and the rate of inflation can affect on the life insurance demands. A number of studies examined the effects of the macroeconomic variables on the life insurance demands, such as the study by Robertson that tested the life insurance demand function using the sectional data of different countries. Browne and Kim (1993) also examined factors effective in the life insurance demand in 45 developing and developed countries. Royl concentrated his study on 48 developing countries, in which he examined the relation between the development of the life insurance section and the financial development and the market structure of the insurance institutions.

In another comparative study, Truett \& Truett (1990) examined factors effective in the life insurance demands in Mexico and USA. Other researches have examined and studied life insurance demands in a certain country, in which the relationship between the life insurance demands and the financial development and different market structures are examined. In a study by Rubayah \& Zaidi (2000), the relationship between the macroeconomic variables and the life insurance demands is directly examined.

In this section, according to different researches conducted, factors effective in life insurance demand are stated in two groups: those with a direct relationship with life insurance demands and those with a reverse relationship with life insurance demands:

Table 1. Factors effective in life insurance demands

\begin{tabular}{|l|l|}
\hline $\begin{array}{l}\text { Factors with a direct relationship with life } \\
\text { insurance demands }\end{array}$ & $\begin{array}{l}\text { Factors with a reverse relationship with } \\
\text { life insurance demands }\end{array}$ \\
\hline $\begin{array}{l}\text { Level of income, level of education, burden of } \\
\text { supporting (Yarri, 1965) }\end{array}$ & Gender and health (Baseri, 2011) \\
\hline Financial vulnerability (Lin\&Grace, 2005) & Price and rate of saving (Azizi, 2006) \\
\hline $\begin{array}{l}\text { Paid loss, national income, war (Mahdavi, } \\
\text { 2009) }\end{array}$ & Life expectancy (Mahdavi, 2009) \\
\hline Spouse occupation (Baseri, 2011) & Real rate of interest (Tofighi, 2009) \\
\hline Gross national production (Tofighi, 2009) & Aging (Lin\&Grace, 2005) \\
\hline $\begin{array}{l}\text { Motivation of leaving the legacy, final tax rate } \\
\text { (Kapfer, 2007) }\end{array}$ & Expected inflation (Yarri, 1965) \\
\hline $\begin{array}{l}\text { Literacy, per capita income (Niarzadeh Niari, } \\
\text { 1999) }\end{array}$ & Life expectancy (Mahdavi, 2009) \\
\hline
\end{tabular}

History of the research

In the following, some important researches conducted on this subject are mentioned. 
In an article, the effect of the advertising media on selling the insurance products, Aduloju\&Odugbesan (2009) believe that advertising can play an important role in the insurance companies using information diffusion. They also state that:

- The problems of positioning and the low sales of the insurance products are not due to the weak economy of a country, but they are due to the weakness of the insurance companies to manage marketing communications.

- Emphasizing other roles of insurance makes the insurance products more attractive, such as financial intermediary and also its complement role in social security.

- Advertising is effective when it is toward the integrated marketing communications.

- The message and the form of an advertising program must be provided cooperating with the insurance company and the advertising agency to make it suitable.

- Newspaper, television and radio are the major media being used by the insurance companies to offer their products and the insurance companies must also use Internet to promote their advertising programs.

- Choosing a suitable advertising medium is a critical factor of the success of any advertising activity.

- Advertisement has a major effect on the volume of sale and the improvement of the public image of the companies.

- Integrated marketing communications are necessary to create a stable competitive advantage and reduce the conflicts in an organization.

- The accurate and correct coordination between the advertising media being used to introduce the products of an insurance company is very important.

- The absence of the records and data of the budgets and the real costs of the advertisement in the past is the problem of many insurance companies.

Table 2. The most important researches conducted on the life insurance

\begin{tabular}{|l|l|l|l|}
\hline Title of the research & $\begin{array}{l}\text { Name of the } \\
\text { researcher(s) }\end{array}$ & $\begin{array}{l}\text { Purpose of the } \\
\text { research }\end{array}$ & Results of the research \\
\hline $\begin{array}{l}\text { The examination of the } \\
\text { factors effective in } \\
\text { selling life insurances } \\
\text { with an emphasis on the } \\
\text { experience of other } \\
\text { countries and the } \\
\text { reasons of the success of } \\
\text { the insurers in Khorasan }\end{array}$ & $\begin{array}{l}\text { A. (2005) } \\
\text { Therigal, evaluation of the }\end{array}$ & $\begin{array}{l}\text { Identifying the factors } \\
\text { of the success of the } \\
\text { insurance companies } \\
\text { in Mashhad to sell life } \\
\text { insurances }\end{array}$ & $\begin{array}{l}\text { Selling insurance services is } \\
\text { one of the most important } \\
\text { communicational elements } \\
\text { beside other elements such as } \\
\text { advertisement, public } \\
\text { relations and sales promotion }\end{array}$ \\
$\begin{array}{l}\text { effectiveness of TV } \\
\text { advertisement } \\
\text { Parsian life and }\end{array}$ & $\begin{array}{l}\text { Fashami, A. A. } \\
(2009)\end{array}$ & $\begin{array}{l}\text { Increasing the sales of } \\
\text { the life and investment } \\
\text { insurance through } \\
\text { advertisement }\end{array}$ & $\begin{array}{l}\text { TV advertisement has a } \\
\text { desirable direct effect on the } \\
\text { introduction of the products of } \\
\text { Parsian insurance, including }\end{array}$ \\
\hline
\end{tabular}




\section{Macrothink Mnstitutem}

\begin{tabular}{|c|c|c|c|}
\hline investment insurance & & & life and investment insurance \\
\hline $\begin{array}{l}\text { Optimal investment and } \\
\text { consumption decision of } \\
\text { a family with life } \\
\text { insurance }\end{array}$ & $\begin{array}{llr}\text { Kwak, } & \text { M. } & \text { \& } \\
\text { Shin, } & \text { Y. } & \text { \& } \\
\text { Choi, } & & \text { U. } \\
(2011) & & \end{array}$ & $\begin{array}{l}\text { Obtaining the best } \\
\text { combination } \\
\text { consumption of } \\
\text { investment portfolio } \\
\text { using the life } \\
\text { insurance }\end{array}$ & $\begin{array}{l}\text { The optimal combination of } \\
\text { the investment and family's } \\
\text { consumption }\end{array}$ \\
\hline $\begin{array}{l}\text { Cultural practices and } \\
\text { life } \quad \text { insurance } \\
\text { consumption }\end{array}$ & $\begin{array}{lr}\text { Chui, } & \text { A. } \\
\text { Chunk, } \\
\text { (2009) }\end{array}$ & $\begin{array}{l}\text { Identifying the relation } \\
\text { between the cultural } \\
\text { practices and the } \\
\text { differences of different } \\
\text { societies in terms of } \\
\text { life insurance } \\
\text { consumption }\end{array}$ & $\begin{array}{l}\text { Organizations in the countries } \\
\text { with high organizational } \\
\text { sharing tend to take on the } \\
\text { responsibility for the } \\
\text { employees' welfare and buy } \\
\text { group life insurance to support } \\
\text { their employees better }\end{array}$ \\
\hline
\end{tabular}

\section{Method of the research and data analysis}

In this section, the method of the research is described including type of the research, tool of data collection, method of data analysis, population, statistical sample and the sampling method.

\section{Type of the research}

The research is an applied one according to the purpose, is a descriptive-survey one according to data collection and is a correlation one according to data analysis.

\section{Tool of data collection}

In this research, questionnaire is used to gather the opinions of the experts and customers of life insurance. Library studies, books, articles and internet searching are used to collect data of the literature of the subject and examine the history of the research.

The questionnaire was first edited and modified by 15 experts to make sure of its validity. Cronbach's Alpha was calculated using SPSS Software to determine the reliability. The reliability was obtained $72 \%$. So the questionnaire has the desirable reliability.

\section{Method of data analysis}

In this research, Spearman correlation test and the average test were used to examine the strength and the type of the relationship between the independent and dependent variables and Friedman analysis of variance test was used to determine the relative importance of the incentive policies effective in increasing life insurance demands.

\section{Population and the statistical sample}

The population of the research includes two groups as follows: 1) 500 university and non-university experts and specialists specialized in life insurance in Tehran.2) 130,000 clients that have used life insurance in Tehran.

According to the definition, the statistical sample is a limited number of the population that shows the main features of the population. In this research, first 4 questionnaires were sent to any of the two groups above. After collecting and analyzing the answers given, it was observed that there was no significant difference between the answers given by these two groups. So the sample was chosen randomly from the population. According to it and using Cochran sampling formula, the statistical sample was determined 380 people. From 380 questionnaires sent, 348 questionnaires were returned back and among them, 32 questionnaires had problems. So, 317 questionnaires were accepted and analyzed.

\section{Results and discussion}

In this study, $72 \%$ of the respondents were male and $28 \%$ were female. $4 \%$ of the respondents had high school degree, $14 \%$ had associate's degree, $34 \%$ had bachelor degree, $37 \%$ had master degree, and $11 \%$ had degrees higher than master degree. Also, $25 \%$ of the respondents 
were under 30 years old, $42 \%$ were 30 to 39 years old, $18 \%$ were 40 to 49 years old and $15 \%$ were above 50 years old.

According to the measures presented, the hypotheses of any of the measures are proposed in table 3.

Table 3. Hypotheses of any of the measures of the research

\begin{tabular}{|c|c|}
\hline \multirow{10}{*}{$\begin{array}{l}\text { Hypotheses of the } \\
\text { variable } \\
\text { "advertisement" }\end{array}$} & $\begin{array}{l}\text { There is a significant positive relationship between using TV } \\
\text { advertisement and the increase of voluntary insurance (life insurance) } \\
\text { demands. }\end{array}$ \\
\hline & $\begin{array}{l}\text { There is a significant positive relationship between using radio } \\
\text { advertisement and the increase of voluntary insurance (life insurance) } \\
\text { demands. }\end{array}$ \\
\hline & $\begin{array}{l}\text { There is a significant positive relationship between using newspaper } \\
\text { advertisement and the increase of voluntary insurance (life insurance) } \\
\text { demands. }\end{array}$ \\
\hline & $\begin{array}{l}\text { There is a significant positive relationship between using brochures and } \\
\text { the increase of voluntary insurance (life insurance) demands. }\end{array}$ \\
\hline & $\begin{array}{l}\text { There is a significant positive relationship between advertising by } \\
\text { professional magazines and the increase of voluntary insurance (life } \\
\text { insurance) demands. }\end{array}$ \\
\hline & $\begin{array}{l}\text { There is a significant positive relationship between using Internet } \\
\text { advertisement and the increase of voluntary insurance (life insurance) } \\
\text { demands. }\end{array}$ \\
\hline & $\begin{array}{l}\text { There is a significant positive relationship between producing films and } \\
\text { TV serials and the increase of voluntary insurance (life insurance) } \\
\text { demands. }\end{array}$ \\
\hline & $\begin{array}{l}\text { There is a significant positive relationship between using subway and } \\
\text { bus advertisement and the increase of voluntary insurance (life } \\
\text { insurance) demands. }\end{array}$ \\
\hline & $\begin{array}{l}\text { There is a significant positive relationship between informing the } \\
\text { employees of the public companies indirectly and the increase of } \\
\text { voluntary insurance (life insurance) demands. }\end{array}$ \\
\hline & $\begin{array}{l}\text { There is a significant positive relationship between informing the } \\
\text { employees of the private companies indirectly and the increase of } \\
\text { voluntary insurance (life insurance) demands. }\end{array}$ \\
\hline \multirow{3}{*}{$\begin{array}{l}\text { Hypotheses of the } \\
\text { variable } \\
\text { "personal selling" }\end{array}$} & $\begin{array}{l}\text { There is a significant positive relationship between holding sales } \\
\text { meetings and the increase of voluntary insurance (life insurance) } \\
\text { demands. }\end{array}$ \\
\hline & $\begin{array}{l}\text { There is a significant positive relationship between participating in } \\
\text { specialized exhibitions and the increase of voluntary insurance (life } \\
\text { insurance) demands. }\end{array}$ \\
\hline & $\begin{array}{l}\text { There is a significant positive relationship between TV marketing and } \\
\text { the increase of voluntary insurance (life insurance) demands. }\end{array}$ \\
\hline \multirow[t]{2}{*}{$\begin{array}{l}\text { Hypotheses of the } \\
\text { variable " sales } \\
\text { promotion" }\end{array}$} & $\begin{array}{l}\text { There is a significant positive relationship between giving incentive } \\
\text { discounts and the increase of voluntary insurance (life insurance) } \\
\text { demands. }\end{array}$ \\
\hline & $\begin{array}{l}\text { There is a significant positive relationship between giving awards and } \\
\text { gifts and the increase of voluntary insurance (life insurance) demands. }\end{array}$ \\
\hline $\begin{array}{l}\text { Hypotheses of the } \\
\text { variable " public } \\
\text { relations " }\end{array}$ & $\begin{array}{l}\text { There is a significant positive relationship between producing and } \\
\text { broadcasting TV programs on the importance of life insurance and the } \\
\text { increase of voluntary insurance (life insurance) demands. }\end{array}$ \\
\hline
\end{tabular}


There is a significant positive relationship between holding congresses and seminars and the increase of voluntary insurance (life insurance) demands.

\section{Data analysis}

The measures of central tendency and dispersion of any of the questions of the questionnaire were first calculated to analyze the opinions given by people, such as the average and the standard deviation and Kolmogorov-Smirnov test was used to examine the normality of the data, and according to the result of the test, Spearman's test was used to examine the correlation between the variables. The results of testing the hypotheses of the advertisement measures are presented in table 4.

Table 4. The results of Spearman's test of correlation between advertisement and the increase of demands

\begin{tabular}{|c|c|c|c|c|}
\hline Type of test & $\begin{array}{l}\text { Correla } \\
\text { tion } \\
\text { coeffici } \\
\text { ent }\end{array}$ & $\begin{array}{l}\text { Level of } \\
\text { significa } \\
\text { nce }\end{array}$ & $\begin{array}{l}\text { Error } \\
\text { in } \\
\text { percent }\end{array}$ & Result \\
\hline $\begin{array}{c}\text { Spearman's test of } \\
\text { correlation between } \\
\text { using TV advertisement } \\
\text { and the increase of life } \\
\text { insurance demands }\end{array}$ & 0.685 & 0 & $1 \%$ & $\begin{array}{l}\text { There is a significant } \\
\text { correlation. }\end{array}$ \\
\hline $\begin{array}{c}\text { Spearman's test of } \\
\text { correlation between } \\
\text { using radio } \\
\text { advertisement and the } \\
\text { increase of life insurance } \\
\text { demands }\end{array}$ & 0.286 & 0.001 & $1 \%$ & $\begin{array}{c}\text { There is no significant } \\
\text { correlation. }\end{array}$ \\
\hline $\begin{array}{c}\text { Spearman's test of } \\
\text { correlation between } \\
\text { using newspaper } \\
\text { advertisement and the } \\
\text { increase of life insurance } \\
\text { demands }\end{array}$ & 0.554 & 0 & $1 \%$ & $\begin{array}{l}\text { There is a significant } \\
\text { correlation. }\end{array}$ \\
\hline $\begin{array}{l}\text { Spearman's test of } \\
\text { correlation between } \\
\text { producing films and } \\
\text { serials and the increase of } \\
\text { life insurance demands }\end{array}$ & 0.665 & 0 & $1 \%$ & $\begin{array}{l}\text { There is a significant } \\
\text { correlation. }\end{array}$ \\
\hline $\begin{array}{c}\text { Spearman's test of } \\
\text { correlation between } \\
\text { using Internet } \\
\text { advertisement and the } \\
\text { increase of life insurance } \\
\text { demands }\end{array}$ & 0.218 & 0 & $1 \%$ & $\begin{array}{l}\text { There is no significant } \\
\text { correlation. }\end{array}$ \\
\hline $\begin{array}{c}\text { Spearman's test of } \\
\text { correlation between } \\
\text { using brochures and the } \\
\text { increase of life insurance } \\
\text { demands }\end{array}$ & 0.613 & 0 & $1 \%$ & $\begin{array}{l}\text { There is a significant } \\
\text { correlation. }\end{array}$ \\
\hline
\end{tabular}




\begin{tabular}{|c|c|c|c|c|}
\hline $\begin{array}{c}\text { Spearman's test of } \\
\text { correlation between } \\
\text { advertising by } \\
\text { professional magazines } \\
\text { and the increase of life } \\
\text { insurance demands }\end{array}$ & 0.646 & 0 & $1 \%$ & $\begin{array}{c}\text { There is a significant } \\
\text { correlation. }\end{array}$ \\
\hline $\begin{array}{c}\text { Spearman's test of } \\
\text { correlation between } \\
\text { using subway and bus } \\
\text { advertisement and the } \\
\text { increase of life insurance } \\
\text { demands }\end{array}$ & 0.193 & 0.001 & $1 \%$ & $\begin{array}{c}\text { There is no significant } \\
\text { correlation. }\end{array}$ \\
\hline $\begin{array}{l}\text { Spearman's test of } \\
\text { correlation between } \\
\text { informing the employees } \\
\text { of the public companies } \\
\text { indirectly and the } \\
\text { increase of life insurance } \\
\text { demands }\end{array}$ & 0.774 & 0 & $1 \%$ & $\begin{array}{c}\text { There is a significant } \\
\text { correlation. }\end{array}$ \\
\hline $\begin{array}{c}\text { Spearman's test of } \\
\text { correlation between } \\
\text { informing the employees } \\
\text { of the private companies } \\
\text { indirectly and the } \\
\text { increase of life insurance } \\
\text { demands }\end{array}$ & 0.753 & 0 & $1 \%$ & $\begin{array}{c}\text { There is a significant } \\
\text { correlation. }\end{array}$ \\
\hline
\end{tabular}

According to the results obtained and supporting 7 measures from the total 10 advertisement measures, it can be concluded that using advertisement increases the life insurance demands. In the following table, the results of testing the hypotheses of the personal selling measures are presented.

Table 5. The results of Spearman's test of correlation between personal selling and the increase of demands

\begin{tabular}{|c|c|c|c|c|}
\hline Type of test & $\begin{array}{c}\text { Correlati } \\
\text { on } \\
\text { coefficient }\end{array}$ & $\begin{array}{c}\text { Level of } \\
\text { significance }\end{array}$ & $\begin{array}{c}\text { Error in } \\
\text { percent }\end{array}$ & Result \\
\hline $\begin{array}{c}\text { Spearman's test of correlation } \\
\text { between holding sales } \\
\text { meetings and the increase of } \\
\text { life insurance demands }\end{array}$ & 0.741 & 0 & $1 \%$ & $\begin{array}{c}\text { There is a } \\
\text { significant } \\
\text { correlation. }\end{array}$ \\
\hline $\begin{array}{c}\text { Spearman's test of correlation } \\
\text { between participating in } \\
\text { specialized exhibitions of } \\
\text { insurance and the increase of } \\
\text { life insurance demands }\end{array}$ & 0.627 & 0 & $1 \%$ & $\begin{array}{c}\text { There is a } \\
\text { significant } \\
\text { correlation. }\end{array}$ \\
\hline $\begin{array}{c}\text { Spearman's test of correlation } \\
\text { between introducing the } \\
\text { products and the performance } \\
\text { of the company through TV } \\
\text { marketing and the increase of }\end{array}$ & 0.638 & 0 & $1 \%$ & $\begin{array}{c}\text { There is a } \\
\text { significant } \\
\text { correlation. }\end{array}$ \\
\hline
\end{tabular}


According to the results obtained and supporting all of the personal selling measures, it can be concluded that using personal selling increases the life insurance demands. In the following table, the results of testing the hypotheses of the sales promotion measures are presented.

Table 6. The results of Spearman's test of correlation between sales promotion and the increase of demands

\begin{tabular}{|c|c|c|c|c|}
\hline Type of test & $\begin{array}{c}\text { Correlation } \\
\text { coefficient }\end{array}$ & $\begin{array}{c}\text { Level of } \\
\text { significance }\end{array}$ & $\begin{array}{c}\text { Error in } \\
\text { percent }\end{array}$ & Result \\
\hline $\begin{array}{c}\text { Spearman's test of } \\
\text { correlation between giving } \\
\text { incentive discounts and the } \\
\text { increase of life insurance } \\
\text { demands }\end{array}$ & 0.701 & 0 & $1 \%$ & $\begin{array}{c}\text { There is a } \\
\text { significant } \\
\text { correlation. }\end{array}$ \\
\hline $\begin{array}{c}\text { Spearman's test of } \\
\text { correlation between giving } \\
\text { awards and gifts and the } \\
\text { increase of life insurance } \\
\text { demands }\end{array}$ & 0.676 & 0 & $1 \%$ & $\begin{array}{c}\text { There is a } \\
\text { significant } \\
\text { correlation. }\end{array}$ \\
\hline
\end{tabular}

According to the results obtained and supporting all of the sales promotion measures, it can be concluded that using sales promotion increases the life insurance demands. In the following table, the results of testing the hypotheses of the public relations measures are presented.

Table 7. The results of Spearman's test of correlation between public relations and the increase of demands

\begin{tabular}{|c|c|c|c|c|}
\hline Type of test & $\begin{array}{c}\text { Correlation } \\
\text { coefficient }\end{array}$ & $\begin{array}{c}\text { Level of } \\
\text { significance }\end{array}$ & $\begin{array}{c}\text { Error in } \\
\text { percent }\end{array}$ & Result \\
\hline $\begin{array}{c}\text { Spearman's test of } \\
\text { correlation between } \\
\text { holding insurance } \\
\text { congresses and seminars } \\
\text { and the increase of life } \\
\text { insurance demands }\end{array}$ & 0.594 & 0 & $1 \%$ & $\begin{array}{c}\text { There is a } \\
\text { significant } \\
\text { correlation. }\end{array}$ \\
\hline $\begin{array}{c}\text { Spearman's test of } \\
\text { correlation between } \\
\text { producing and } \\
\text { broadcasting TV } \\
\text { programs to inform and } \\
\text { educate the public and } \\
\text { the increase of life } \\
\text { insurance demands }\end{array}$ & 0.652 & 0 & $1 \%$ & $\begin{array}{c}\text { There is a } \\
\text { significant } \\
\text { correlation. }\end{array}$ \\
\hline
\end{tabular}

According to the results obtained and supporting all of the public relations measures, it can be concluded that using public relations increases the life insurance demands.

\section{Ranking incentive policies effective in increasing life insurance demands}

In this section, Freidman test is used to rank and determine the incentive policies effective in increasing life insurance demands. According to the rank average comparison of the various factors based on non-parametric data, Friedman analysis of variance test is a suitable test.

The statistical hypotheses of the test are as follows: 


\section{Macrothink Mnstitutem}

The first hypothesis:

$H_{0}$ : there is no significant difference between the effectiveness of the measures of the incentive policies.

$H_{1}$ : there is a significant difference between the effectiveness of the measures of the incentive policies.

The results of the statistical analysis of the data of the questionnaire on this hypothesis are presented in table 8 .

Table 8. The results of Friedman analysis of variance test

\begin{tabular}{|c|c|c|c|}
\hline Chi-square & $\begin{array}{c}\text { Level of } \\
\text { significance }\end{array}$ & Error in percent & Result \\
\hline 3025.54 & 0.00 & $1 \%$ & $\begin{array}{c}\text { There is a significant } \\
\text { difference }\end{array}$ \\
\hline
\end{tabular}

Since the significance level of Friedman analysis of variance test is less than the error, $H_{1}$ is supported. In other words, $H_{0}$ is rejected at the level of confidence $99 \%$. Therefore, it can be said that there is a significant difference between the effectiveness of the measures of the incentive policies. The results of the analysis are presented in table 9.

Table 9. Ranking and determining incentive policies effective in increasing life insurance demands

\begin{tabular}{|c|c|c|}
\hline Rank & Factors & Rank average \\
\hline 1 & $\begin{array}{c}\text { Informing the employees of the private companies } \\
\text { indirectly by paying a part of the costs by the company's } \\
\text { managers }\end{array}$ & 14.31 \\
\hline 2 & $\begin{array}{c}\text { Informing the employees of the public companies } \\
\text { indirectly by paying a part of the costs by the company's } \\
\text { managers }\end{array}$ & 14.14 \\
\hline 3 & Holding sales meetings & 14.11 \\
\hline 4 & Giving incentive discounts & 12.76 \\
\hline 5 & Giving awards and gifts & 10.73 \\
\hline 6 & Producing life insurance-based films and TV serials & 9.97 \\
\hline 7 & Introducing the products and the performance of the & 9.80 \\
\hline 8 & company through TV marketing & 9.33 \\
\hline 9 & Holding insurance congresses and seminars & 9.19 \\
\hline 10 & Using TV advertisement & 8.55 \\
\hline 11 & Participating in specialized exhibitions of insurance & 8.53 \\
\hline 12 & Using brochures & 8.21 \\
\hline 13 & $\begin{array}{c}\text { Producing and broadcasting TV programs to inform and } \\
\text { educate the public on the importance of life insurance }\end{array}$ & 7.56 \\
\hline 14 & Using newspaper advertisement & 6.090 \\
\hline
\end{tabular}

As it is observed in the table above, the highest rank is for informing the employees of the private companies indirectly by paying a part of the costs by the company's managers and the lowest rank is for using newspaper advertisement.

\section{Conclusions}

The results obtained from examining the hypotheses of the advertisement using Spearman's correlation coefficient test and the average test showed that using TV advertisement, newspaper advertisement, brochures, producing life insurance-based films and TV serials, 
informing the employees of the public companies indirectly by paying a part of the costs by the company's managers, advertising by professional magazines and informing the employees of the private companies indirectly by paying a part of the costs by the company's managers increase the life insurance demands. Also for the hypotheses of the personal selling, Spearman's correlation coefficient test and the average test showed that holding sales meetings to sell life insurance policies, participating in specialized exhibitions of insurance and introducing the products and the performance of the company through TV marketing increase the life insurance demands. Spearman's correlation coefficient test and the average test for the hypotheses of the sales promotion showed that giving incentive discounts and giving awards and gifts increase the life insurance demands. Finally, Spearman's correlation coefficient test and the average test for the hypotheses of the public relations showed that holding insurance congresses and seminars and producing and broadcasting TV programs to inform and educate the public on the importance of life insurance increase the life insurance demands.

Also, the results from Friedman analysis of variance test showed that the measures including informing the employees of the private companies indirectly by paying a part of the costs by the company's managers, informing the employees of the public companies indirectly by paying a part of the costs by the company's managers, holding sales meetings, giving incentive discounts, giving awards and gifts, producing life insurance-based films and TV serials, introducing the products and the performance of the company through TV marketing, advertising by professional magazines, holding insurance congresses and seminars, using TV advertisement, participating in specialized exhibitions of insurance, using brochures, producing and broadcasting TV programs to inform and educate the public on the importance of life insurance, and using newspaper advertisement had respectively the first to the fourteenth rank for increasing life insurance demands.

The purpose of the research was to identify the incentive policies effective in increasing the life insurance demands and determine the level of the relative importance of any of the measures being examined. According to the data collected by the researcher and using Spearman's correlation test, the hypotheses of the research were supported. Also, the results from Friedman analysis of variance showed that some measures were more effective.

For example, the results from the section "advertisement" show that informing the employees of the private companies indirectly and informing the employees of the public companies indirectly are more effective in increasing life insurance demands.

Overall, the main findings of the research can be summarized as follows:

- Identifying the incentive policies effective in increasing life insurance demands

- Indentifying a positive relationship between advertisement and the increase of life insurance demands

- Indentifying a positive relationship between personal selling and the increase of life insurance demands

- Identifying a positive relationship between sales promotion and the increase of life insurance demands

- Identifying a positive relationship between public relations and the increase of life insurance demands

Overall according to the results of the research and taking the questions of the research into account, it can be concluded that using effective incentive policies by the insurance companies 
can increase the life insurance demands and this also improves the tendency of people to buy life insurance policies from the insurance companies.

\section{Suggestions based on the results of the research}

- According to the results of the research, using the incentive policies including informing the employees of the private companies indirectly and informing the employees of the public companies indirectly (paying a part of the costs of these insurance policies by the company's managers) respectively as the first and the second ranks were known as the incentive policies of the research. Therefore, it is suggested that companies offering life insurance pay special attention to these policies to increase the demands for such these insurance policies.

- Also according to the results of the research, holding sales meetings to sell life insurance policies, giving incentive discounts, giving awards and gifts, producing life insurance-based films and TV serials, introducing the products and the performance of the company through TV marketing, advertising by professional magazines, holding insurance congresses and seminars, using TV advertisement, participating in specialized exhibitions of insurance, using brochures, producing and broadcasting TV programs to inform and educate the public on the importance of life insurance, and using newspaper advertisement are the incentive policies effective in increasing life insurance demands and it is suggested that companies offering life insurance use these policies.

- The education units of the insurance companies must constantly transfer the knowledge about the incentive policies to the employees and the experts. The skills of communicating with customers, advertisement and negotiation must be also educated to all of the employees working in the divisions and the agencies of these companies.

Finally, it is recommended that the insurance companies:

- Form market research units to get exact information of the customers and ask their opinions and demands and also analyze their demands and behaviors constantly. The output of these processes plays an important role in increasing the effectiveness of the incentive policies of the companies offering life insurance.

- For evaluating the incentive policies implemented, provide various suitable communication tools and processes to get the feedback of the customers personally and non-personally in order that the customers are easily able to state their opinions and views about the content and the effectiveness of the policies.

\section{References}

1. Agha Mohseni Fashami, A. (2009), The evaluation of the effectiveness of TV advertisement of Parsian life and investment insurance, master thesis, Tehran University.

2. Baseri, B., Emamverdi, Q., Daghighi Asl, A., \& Baratpour, M. (2011), factors effective in buying life insurance, journal of insurance, 101, pp. 1-30. 


\section{Macrothink

3. Bagheri Gigal, A. (2005), The examination of the factors effective in selling life insurances with an emphasis on the experience of other countries and the reasons of the success of the insurers in Khorasan (the cases study: Mashhad), the quarterly journal of insurance industry, 2, pp. 63-82.

4. Tajdar, R. (1996), the examination of the reasons of the non-development of the life insurance in Iran, master thesis, Tehran University.

5. Tofighi, T. (2009), the examination of the effect of the inflation on life insurance demands in Iran during 1981-2006, master thesis, Islamic Azad University, Firouzkouh Branch.

6. Hafeznia, M. (2004), an introduction to the method of research in human sciences, Samt Pub., Tehran.

7. Heidari Choroudeh, M. \& Foroughzadeh, S. (2011), an applied manual of SPSS Software with an emphasis on the method of research and statistics, Jameshenasan Pub., Tehran.

8. Khaki, Q. (2003), the method of research with an approach of dissertation writing, Baztab Pub., Tehran.

9. Azizi, F. (2006), the relation between macroeconomic variables and life insurance demands in Iran, the quarterly journal of human sciences instructor, 4, pp. 135-149.

10. Mahdavi, Q. (2009), the examination of the factors effective in the life insurance demands in Iran, master thesis, faculty of social sciences, Alzahra University.

11. Niarzadeh Niari, A. (1999), the identification and determination of the most important factors effective in the life insurance demands in Iran and the presentation of a suitable model, master thesis, Tehran University.

12. Aduloju, A. \& Odugbesan,O. \& Oke, S. (2009). The effects of advertising media on sales of insurance products: a developing-country case, Journal of Risk Finance, 10, pp. $210-227$.

13. Browne, M. \& Kim K. (1985), An international analysis of life insurance demand, Journal of risk \& Insurance, 40, pp. 616- 634.

14. Chui, A. \& Chuck, C. (2009), Cultural practices and life insurance consumption: An international analysis using GLOBE scores, Journal of Multinational Financial Management, 19, pp. 273-289.

15. Kapfer, J. (2007), Three essays in empirical economics, <http://www.edoc.ub.uni-muenchen.de/8004/1/Kapfer_Joy. pdf>.

16. Kwak, M. \& Shin, Y. \& Choi, U . (2011), Optimal investment and consumption decision of a family with life insurance, Insurance: Mathematics and Economics, 48, pp. 176 $-193$.

17. Lin, Y. \& Grace, D. (2005), Household life cycle protection: life insurance holdings, financial vulnerability and portfolio implications, <http://www.econpaper.com>.

18. Rubayah ,Y. \& Zaidi, I. (2000), Prospect industry insurance hayat abad ke-21, Ultra Management Review, 1, pp. 69-79. 
19. Truett, D. \& Truett, L. (1990), The demand for life insurance in Mexico and the united states: A comparative study, Journal of Risk and Insurance, 57, pp. 321-328.

20. Yarri, M. (1965), Uncertain lifetime, life insurance and theory of the consumer, Review of Economic Studies, 32, pp. 137-151. 